\title{
Assessment of the Ecological Potential of the Soła River Cascade on the Basis of the Selected Biological Indicators
}

\author{
Anna Salachna ${ }^{1 *}, Z^{2}$ uzanna Olearczyk ${ }^{1}$ \\ 1 University of Bielsko-Biala, Institute of Environmental Protection and Engineering, Willowa 2, \\ 43-309 Bielsko-Biała, Poland \\ * Corresponding author's e-mail: asalachna@ath.bielsko.pl
}

\begin{abstract}
The paper presents an assessment of the ecological potential of the Sola river based on the benthic macroinvertebrates and diatomaceous phytobenthos, according to the principles of the Water Framework Directive. The calculated values of Multimetric Diatom Index (IO) indicated class II of ecological potential, while the Multimetric Macroinvertebrate Index (MMI_PL) - class III. The final classification of biological, physicochemical and hydromorphological elements showed that the examined section of the Soła river represents a moderate ecological potential which indicates a moderate disruption in the functioning of the water ecosystem as well as a violation of the hydrological regime and morphological conditions of the riverbed.
\end{abstract}

Keywords: biological indicators, ecological potential, water quality, MMI_PL, IO

\section{INTRODUCTION}

The quality of water is a very important issue for the life and functioning of all organisms in the world. Water is the basic component of the global ecosystem which provides people with different ecosystem services, i.e. supply in drinking water, regulating of climate (hydrological cycle) and nonmaterial benefits (aesthetic values, tourism and recreation) [Millenium Ecosystem Assessment 2005].

In Europe, the surface water monitoring is currently carried out according to the principles of the Water Framework Directive (WFD), according to which the ecological and chemical status/potential of Surface Water Bodies is assessed. The biological elements are of fundamental importance in this assessment, while hydromorphological and the physicochemical elements have only an auxiliary function [Water Framework Directive 2000]. In Poland, the surface water monitoring is one of the subsystems of the State Environmental Monitoring. The Voivodship Inspectorates for Environmental Protection are responsible for conducting relevant tests in accordance with the guidelines set out in the Regulation of the Minister of the Environment on the classification of the surface water bodies and environmental quality standards for priority substances [Journal of Laws, 2016, item 1187]. Monitoring of surface water bodies identified as artificial or heavily modified is particularly important. This group includes the cascade sections of rivers, i.e. the river and dam reservoirs formed on it. The Sola Cascade has many different functions, among which energy production (utilization of the energy potential of flows) and drinking water supply for people are the most important.

The main purpose of this work is to assess the ecological potential of the Sola river cascade based on benthic macroinvertebrates and diatomaceous phytobenthos according to the principles of the Water Framework Directive.

\section{MATERIAL AND METHODS}

\section{Study site}

The studied section of the Soła river belongs to two heavily transformed Surface Water 
Bodies identified as: the cascade of the Sola from the Tresna Reservoir to the Czaniec Reservoir (code RW2000021329553) and Sola from the Czaniec Reservoir to the estuary (code RW2000015213299). In terms of abiotic factors, it represents a mediumsized carbonate upland river [Hobot 2014]. Administratively, it is located in the Żywiec and Bielsko poviats in the Śląskie Voivodeship.

In order to assess of ecological potential of the Sola Cascade three sampling sites located in Porąbka (1), Czaniec (2) and Kobiernice (3) were selected (Fig. 1). Their choice was mainly determined by the diversity of habitat conditions, land use of adjacent areas, location relative to stagnant water bodies and anthropogenic buildings, as well as accessibility for the researcher. The selected points were similar in terms of these factors.

\section{Biological, physicochemical and hydromorphological analyses}

The field studies were conducted from September 2018 to March 2019. The sampling of benthic macroinvertebrates was carried out in accordance with the Multi Habitat Sampling (MHS) method [EN 16150:2012 European standard, Directive 2014/101/EU]. Diatomaceous phytobenthos were collected following the ENPN 13946 standard. For the purification of diatoms, a hot hydrogen peroxide method was used. The cleaned silica frustules were mounted with Naphrax ${ }^{\circledR}$ resin on permanent slides. The taxonomic identification of the investigated organisms was carried out to the family level (in the case of macroinvertebrates) and to the species level (in the case of phytobenthos) by means of a Prolab stereoscopic microscope and a Nikon Eclipse E 200 optical microscope with a Delta Pix Invenio 5S digital camera. The abundance of families of zoobenthos was obtained by directly counting all observed individuals in the samples, whereas the abundance of diatom species was obtained by counting thecae in subsequent fields of view of the microscope along the transect on the permanent slides (until a total of 400 thecae was obtained).

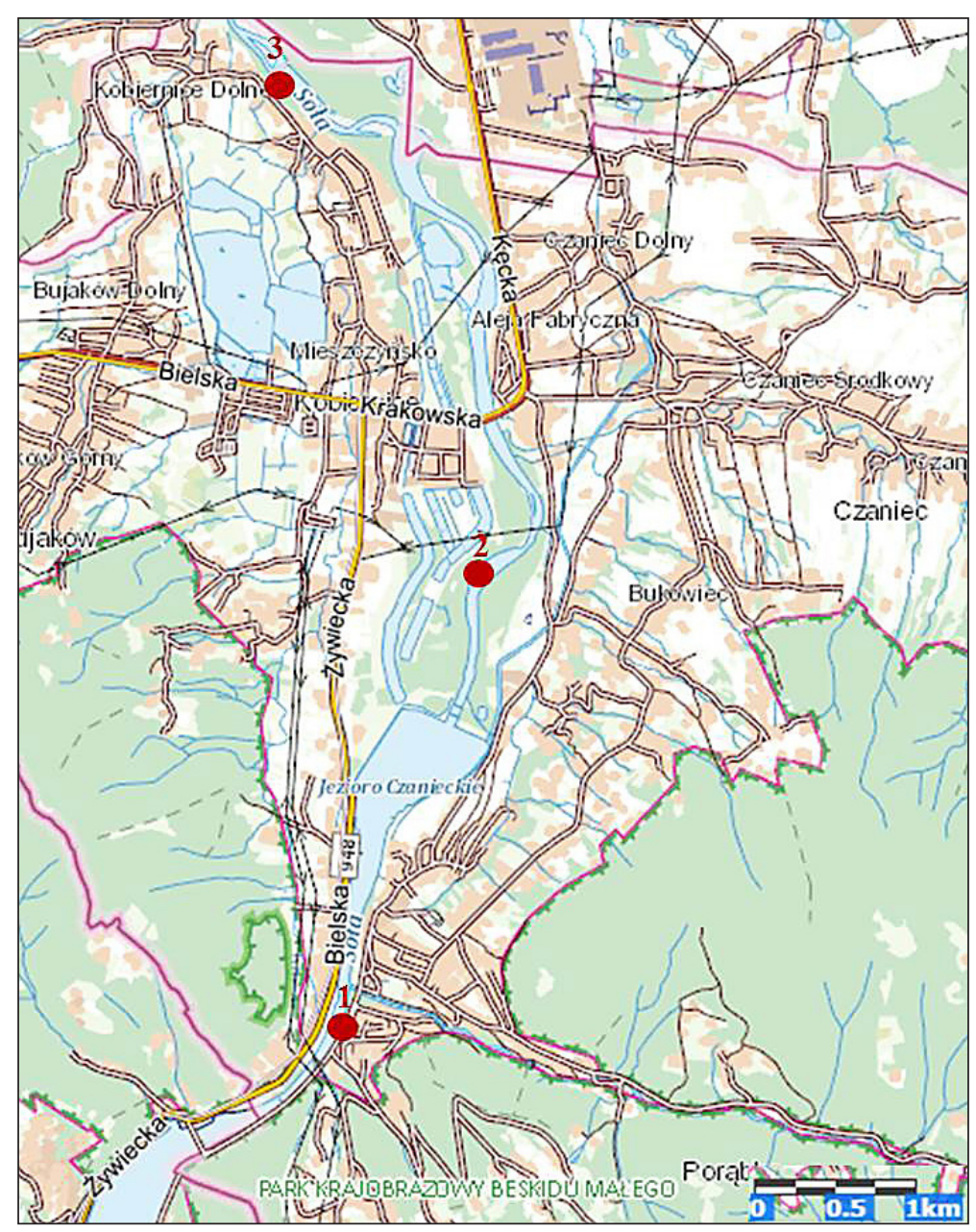

Fig. 1. Map of the study area (www.geoportal.gov.pl) 
The collected data on the diversity of macroinvertebrates and phytobenthos of the Sola river were used to calculate the Multimetric Macroinvertebrate Index (MMI_PL) based on the algorithm developed by Bis, Mikulec [2013] and the Multimetric Diatom Index (IO) according to the formula given by Zgrundo et al. [2018].

In addition, the physicochemical analyses of water were performed (Table 3). Some of them (temperature, conductivity and $\mathrm{pH}$ ) were measured in situ using a CX-401 multifunction meter. For the remaining analyses, the water samples were taken in accordance with the guidelines for sampling from rivers and streams [PN-ISO 5667-6]. For this purpose, the plastic bottles were immersed under the surface of the water, to a depth enabling the water to be taken in from the zone above the benthic zone. The water samples were delivered to the laboratory tightly closed, described and with limited light access. Until the determinations were carried out, they were stored in a refrigerator at $4^{\circ} \mathrm{C}$. Individual parameters were determined according to the methods specified in the following PN-EN standards: concentration of nitrite - spectrophotometric method PN-EN 26777; concentration of nitrate - spectrophotometric method with sodium salicylate in a sulfuric acid medium PN-82 C-04576.08; concentration of ammonia spectrophotometric method PN-ISO 7150-1; dissolved oxygen - iodometric method PN-EN 25813, PN-ISO 5813; BOD $_{5}$ - PN-EN 18991-2; alkalinity - in the presence of phenolphthalein indicator PN-EN ISO 9963-1.

The assessment of hydromorphological elements and final classification of ecological potential of Soła river was carried out in accordance with the guidelines set out in Annex 8 to the Regulation...2016 [Journal of Laws, 2016, item 1187].

\section{RESULT AND DISCUSSION}

\section{Biodiversity of macrofauna and phytobenthos}

In total, nine macroinvertebrate taxa were found on the examined section of the Sola river (Table 1). Two of them: amphipods from the Crangonyctidae Bousfield family and isopods from the Asselidae Latreille family were dominant. Their highest density was recorded on the first investigated station, where it reached the values of almost 494 and 282 ind. $/ \mathrm{m}^{2}$, respectively. The most sensitive taxa were two families of the caddisflies: Limnephilidae Kolenati and Rhyacophilidae Stephens which were assigned 7 scores in the BMWP-PL scoring system [Kownacki, Soszka 2004]. During the field study, two individuals of the species Orconectes limosus (Raf.) (family Cambaridae) were found. It is an invasive species, whose natural area of occurrence is North America [Hamr 2002]. Its presence in the studied rivers is unfavorable, because it can displace the native species of crayfish [Schulz et al. 2006]. The fast water current and the unevenness of flows, associated with the operation of hydroelectric power stations, creates unfavorable habitat conditions for the existence of benthic macroinvertebrates. Organic matter is washed away by the water current and transported down the river. The content of organic matter in the substrate directly affects the concentration of macrofauna [Zdoliński et al. 2009]. The presence of a dam causes disturbance in the migration of aquatic organisms [Kasza 2009].

A total of 24 diatom species were identified in the study river (Table 2). Most of them are cosmopolitan species found in various types of habitats. Diatoma vulgaris Bory and Encyonema minutum (Hilse) (Fig. 3) dominated in terms of

Table 1. List of macroinvertebrate families and their average density in the study sites $(*$ indicator taxa have been marked with an asterisk)

\begin{tabular}{|c|l|c|c|c|}
\hline \multirow{2}{*}{ Class/Order } & \multirow{2}{*}{ Family } & \multicolumn{3}{c|}{ Average density (ind./ ${ }^{2}$ ) } \\
\cline { 3 - 5 } & & 1 & 2 & 3 \\
\hline Amphipoda & Crangonyctidae Bousfield & 493.75 & 37.5 & 106.25 \\
\hline Decapoda & Cambaridae Hobbs & 12.5 & - & - \\
\hline Diptera & Tipulidae Latreille* & - & - & 6.25 \\
\hline Gastropoda & Lymneidae Rafinesque* & 6.25 & 12.5 & 43.75 \\
\hline Isopoda & Asselidae Latreille* & 281.5 & 100 & 93.75 \\
\hline Oligochaeta* & - & 31.25 & - & - \\
\hline \multirow{2}{*}{ Trichoptera } & Limnephilidae Kolenati* & 50 & 6.25 & 43.75 \\
\cline { 2 - 5 } & Hydropsychidae Curtis* & 41.62 & 31.25 & 6.25 \\
\cline { 2 - 5 } & Rhyacophilidae Stephens* & - & - & 6.25 \\
\hline
\end{tabular}


Table 2. List of phytobenthic diatoms species in the Soła river $(*$ species indicator for carbonate river have been marked with an asterisk)

\begin{tabular}{|c|c|c|c|}
\hline \multirow{2}{*}{ Species } & \multicolumn{3}{|c|}{ Abundance (number of thecae) } \\
\hline & 1 & 2 & 3 \\
\hline Cocconeis placentula Ehrenberg & - & 11 & - \\
\hline Diatoma ehrenbergii Kützing* & - & - & 1 \\
\hline Diatoma mesodon (Ehrenberg) Kützing* & 4 & 8 & 2 \\
\hline Diatoma moniliformis (Kützing) Williams* & 19 & - & 9 \\
\hline Diatoma problematica Lange-Bertalot & 16 & 59 & 25 \\
\hline Diatoma vulgaris Bory & 63 & 115 & 113 \\
\hline Didymosphenia geminata (Lyngbye) Schmidt* & - & 25 & 4 \\
\hline Encyonema prostratum (Berkeley) Kützing & 1 & 19 & - \\
\hline Encyonema minutum (Hilse) Mann* & 174 & - & 119 \\
\hline Encyonema ventricosum (Agardh) Grunow & 47 & 31 & - \\
\hline Encyonema vulgare Krammer & 25 & 25 & 16 \\
\hline Fragilaria recapitellata Lange-Bertalot i Metzeltin* & 6 & 25 & 32 \\
\hline Fragilaria vaucheriae (Kützing) Petersen & - & - & 15 \\
\hline Gomphonema minutum (Agardh) Agardh & 1 & 7 & 5 \\
\hline Gyrosigma acuminatum (Kützing) Rabenhorst & - & 2 & - \\
\hline Melosira varians Agardh & 4 & 7 & 25 \\
\hline Navicula lanceolata Mann, Droop & 11 & 50 & 15 \\
\hline Nitzchia gracilis Hantzsch & 4 & 3 & - \\
\hline Nitzchia intermedia Hantzsch & - & 3 & 1 \\
\hline Pinnularia brauniana (Grunow) Mills & 5 & - & - \\
\hline Roicosphenia abbreviata (Agardh) Lange-Bertalot & 4 & 3 & - \\
\hline Surirella brebissoni Krammer, Lange-Bertalot ${ }^{\star}$ & 13 & 7 & 17 \\
\hline Surirella spiralis Kützing & 3 & - & - \\
\hline Ulnaria ulna (Nitzsch) Compère & - & - & 1 \\
\hline Total & 400 & 400 & 400 \\
\hline
\end{tabular}

Table 3. Physicochemical parameters of water at the studied sites of Soła river

\begin{tabular}{|l|c|c|c|}
\hline \multirow{2}{*}{ Parameters } & \multicolumn{3}{c|}{ Study sites } \\
\cline { 2 - 4 } & 1 & 2 & 3 \\
\hline Conductivity $(\mu \mathrm{S} / \mathrm{cm})$ & 168 & 170 & 175 \\
\hline Temperature $\left({ }^{\circ} \mathrm{C}\right)$ & 4 & 3 & 4 \\
\hline $\mathrm{pH}$ & 7.42 & 7.49 & 7.57 \\
\hline Dissolved oxygen $\left(\mathrm{mgO}_{2} / \mathrm{dm}^{3}\right)$ & 13.55 & 11.49 & 11.33 \\
\hline $\mathrm{NO}_{2}\left(\mathrm{mgNO}_{2} / \mathrm{dm}^{3}\right)$ & 0.026 & 0.029 & 0.008 \\
\hline $\mathrm{NO}_{3}\left(\mathrm{mgNO}_{3} / \mathrm{dm}^{3}\right)$ & 3.390 & 2.571 & 4.422 \\
\hline $\mathrm{NH}_{4}\left(\mathrm{mgNH}_{4}{ }^{+} / \mathrm{dm}^{3}\right)$ & 0.022 & 0.028 & 0.010 \\
\hline${\mathrm{Alkalinity}\left(\mathrm{mgCaCO}_{3} / \mathrm{dm}^{3}\right)}^{\mathrm{n}}$ & 64 & 62 & 66 \\
\hline $\mathrm{BOD}_{5}\left(\mathrm{mgO}_{2} / \mathrm{dm}^{3}\right)$ & 2.39 & 0.65 & 0.49 \\
\hline
\end{tabular}

abundance. $D$. vulgaris prefers eutrophic waters while the E. minutum more often occurs under mesotrophic conditions [Bąk et al. 2012]. It confirms the earlier observations of other authors about the trophic state of the examined part of the Soła [Jaguś 2011; Jachniak, Jaguś 2013]. It is also worth emphasizing the occurrence of the
Didymosphenia geminata (Lyngbe) M. Schmidt species (Fig. 2), because its spread in Europe and in other continents has recently been documented [Whitton et al. 2009].

\section{Ecological potential of the Soła river}

The biological assessment pertaining to the ecological potential of the Sola river, conducted on the basis of the applied indices, showed slighty different results (Fig. 4). The values of the MMI PL index fluctuated between 0.53 and 0.62 . The IO index ranged from 0.43 to 0.51 , with the lowest values in the second of the investigated sites. On the basis of the limits of biological indicators set out in Annex 5 of Regulation...[2016] the examined sites were classified to ecological potential class. The MMI_PL index qualified the water in all examined stands to third class, whereas the index IO index indicated third class at the second stand and second class at first and third stand (Fig. 2). These results partly overlap with the measurements of these biological indicators carried 

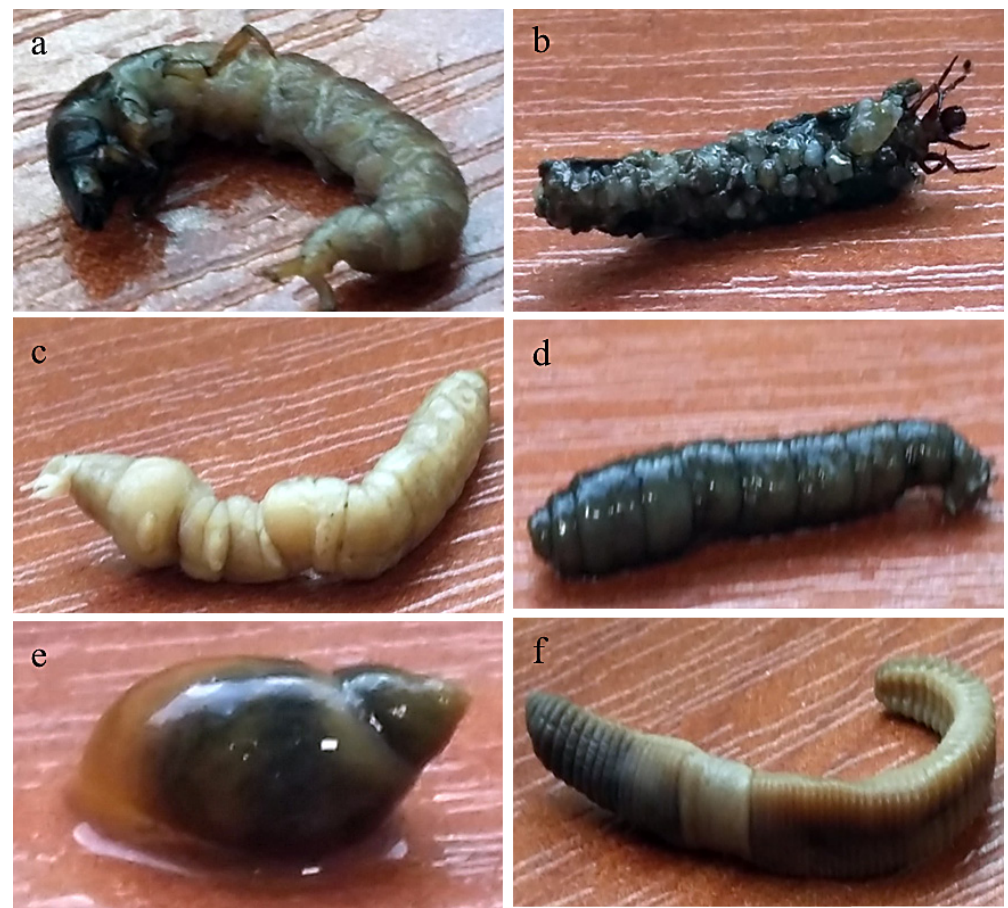

Fig. 2. Selected macroinvertebrate taxa occurring in the benthic zone of the Sola river: a. Hydropsychidae; b. Limnephilidae; c-d. Tipulidae; e. Lymneidae; f. Oligochaeta
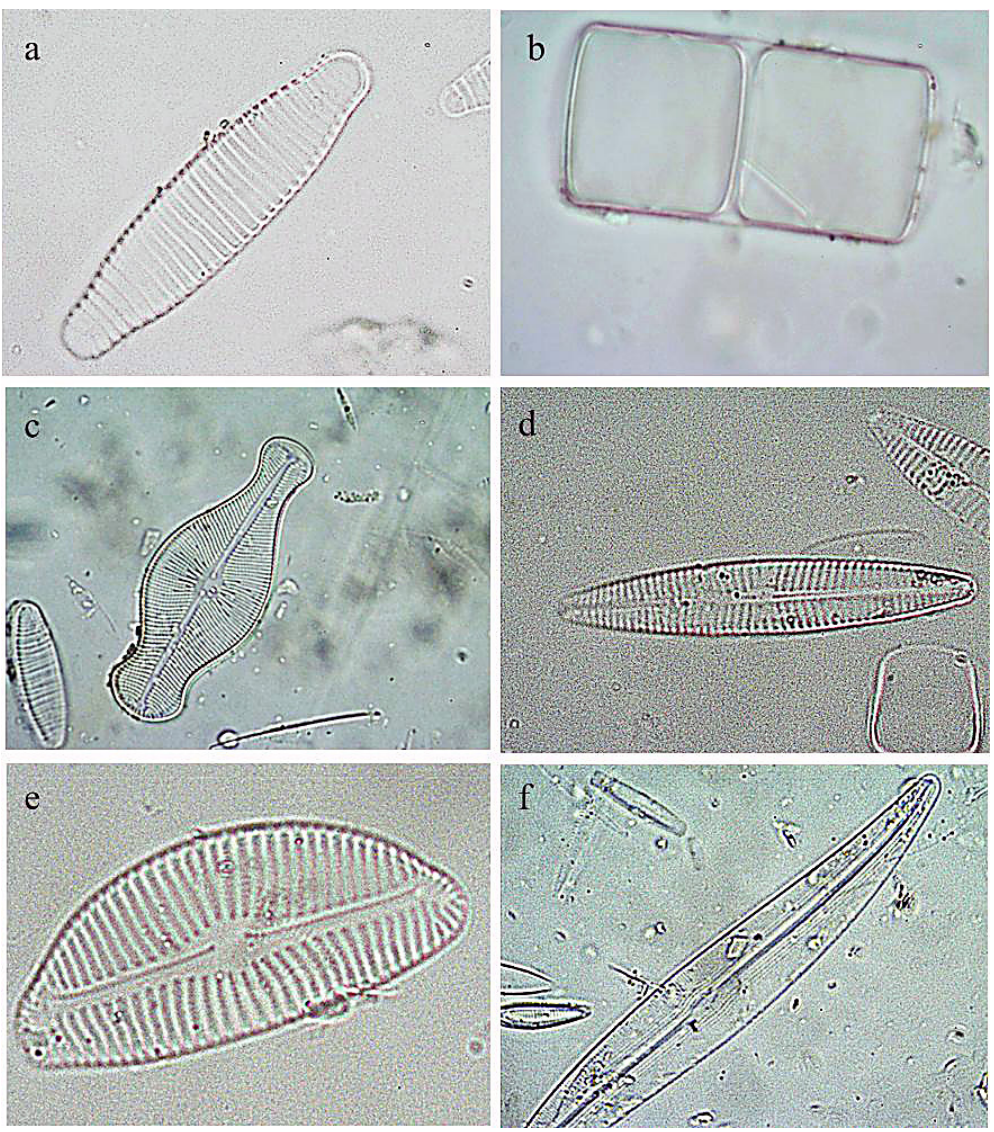

Fig. 3. Selected diatom species identified in the examined section of the Sola river: a. Diatoma vulgaris (x1000); b. Melosira varians, (x1000); c. Didymosphenia geminata (x400); d. Navicula lanceolata (x1000); e. Encyonema prostratum (x1000); f. Gyrosigma acuminatum (x400). 


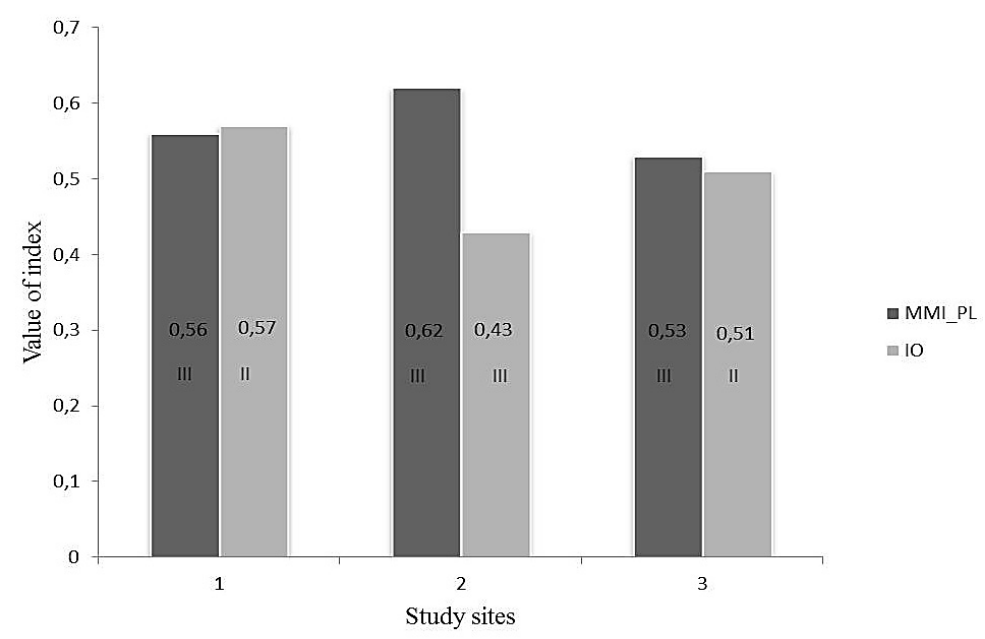

Fig. 4. Values of indices applied to assessment of ecological potential of the Soła river (II, III - class of ecological potential according of Regulation.....2016)

out by Voivodship Inspectorate for Environmental Protection in the framework of surface water monitoring [http://www.katowice.pios.gov.pl].

The obtained values of conductivity, dissolved oxygen, ammonia, alkalinity and $\mathrm{BOD}_{5}$ indicated first class of ecological potential of all investigated sections of the Sola river, while the $\mathrm{pH}$ and nitrites classify them into second class. Among all the analysed physicochemical parameters, only the content of nitrates has not reached the values required for first and second class of water quality. The Regulation... [2016] did not determine the limits values of this parameter for the classes below second.

Maximum ecological potential is attributed to rivers in which the hydromorphological changes are limited only to the changes in the flow volume (SNQ - medium low flow) and are associated with a disruption of the continuity river through the dam. If appropriate protective measures were taken, e.g. in the form of a fish pass, then this section of the river would reach the first class of ecological potential in terms of hydromorphological elements. In other cases, the second class is assigned [Regulation.....2016]. On the basis of these guidelines, the hydromorphological elements at all studies sites of the Sola river were classified in the second class of ecological potential.
The final classification of the ecological potential showed that the examined section of the Sola river represents the third class of ecological potential (Table 4), which means a moderate disruption in the functioning of the water ecosystem as well as a violation of the hydrological regime and morphological conditions of the riverbed [Water Framework Directive 2000].

\section{CONCLUSIONS}

The assessment of the ecological potential of the Soła river carried out in this work shows a partial state of functioning of the aquatic ecosystem. In the future, classification of other biological indicators, i.e. phytoplankton together with chlorophyll a and macrophytes should be carried out. Monitoring of river cascade sections should include the transition fragments between reservoirs, because of their completely different hydromorphological conditions, which have an impact on the obtained values of biological indicators.

The presence of an invasive Orconectes limosus species is a major threat to the studied water ecosystem. The population status of this species should be monitored, as its spread may contribute to the displacement of other native species of aquatic fauna.

Table 4. Final classification of the ecological potential of the Soła river

\begin{tabular}{|c|c|c|c|c|c|}
\hline \multirow{2}{*}{ Study sites } & \multicolumn{2}{|c|}{ Biological elements } & Physicochemical elements & Hydromorphological elements & Final \\
\cline { 2 - 4 } & IO & MMI_PL & blassification \\
\hline 1 & II class & III class & below II class & II class \\
\hline 2 & III class & III class & below II class & II class \\
\hline 3 & II class & III class & below II class class \\
\hline
\end{tabular}




\section{REFERENCES}

1. Bąk M., Witkowski A., Żelazna-Wieczorek J., Wojtal A. Z., Szczepocka E., Szulc K., Szulc B. 2012. Key for the determination of diatoms in phytobenthos for the purposes of assessing the ecological status of surface waters in Poland, Library of Environmental Monitoring, Warsaw [in Polish].

2. Bis B., Mikulec A. 2013. Guide to assess the ecological status of rivers based on benthic macroinvertebrates. Library of Environmental Monitoring, Warsaw [in Polish].

3. Directive 2014/101/EU. Commission Directive 2014/101/EU of 30 October 2014 amending Directive 2000/60/EC of the European Parliament and of the Council establishing a framework for Community action in the field of water policy.

4. EN 13946. 2014. Water quality. Guidelines for routine sampling and preparation of benthic diatoms from rivers and lakes.

5. EN 16150. 2012. Water quality. Guidelines for proportional multi-environment collecting macroinvertebrates from shallow rivers.

6. Hamr P. 2002. Orconectes. Biology of Freshwater Crayfish (ed. Holdich D.M.): 585-589, 600-603.

7. Hobot A. (red). 2014. Updating the list of UBSW and HCUBSW for the purposes of the next update of plans in 2015-2021 along with verification of water types of water bodies. National Fund for Environmental Protection and Water Management, Gliwice, Warsaw [in Polish].

8. Jachniak E., Jaguś A. 2013. Lowering water trophy in cascade systems, on the example of the Sola cascade (southern Poland). Ecological Ecological Engineering 32: 65-73 [in Polish].

9. Jaguś A. 2011. Assessment of the trophic state of the waters of the Soła Cascade reservoirs. Proceedings of ECOpole 5(1), 233-238.

10. Kasza H. 2009. Dam reservoirs. Importance. Eutrophication.Protection, University of Bielsko - Biala, Bielsko-Biała [in Polish].

11. Kownacki A., Soszka H. 2004. Guidelines for assessing the state of rivers based on macroinvertebrates and for sampling macroinvertebrates in lakes. Institute of Environmental Protection, Warsaw [in Polish].

12. Millenium Ecosystem Asssessment 2005. Ecosystems and Human Well-Being. Synthesis, Island Press, Washington.

13. Picińska-Fałtynowicz J., Błachuta J. 2010. Methodical guidelines for assessing the ecological status of river and lake water bodies and the ecological potential of artificial and heavily modified water bodies flowing Poland based on phytobenthos research, report on the work carried out at the request of the
Chief Inspectorate for Environmental Protection, Wrocław [in Polish].

14. PN-C-04576-08. 1982. Water and wastewater. Tests for nitrogen content. Determination of nitrate nitrogen by colorimetric method with sodium salicylate [in Polish].

15. PN-EN 18991-2. 2002. Water quality. Determination of the biochemical oxygen demand after $n$ days (BOD). Part 2: Method for the undiluted samples [in Polish].

16. PN-EN 25813. 1997. Water quality. Determination of the dissolved oxygen. Iodimetric method [in Polish].

17. PN-EN 26777. 1999. Water quality. Determination of nitrite. Molecular absorption spectrometry method [in Polish].

18. PN-EN ISO 9963-1. 2001. Water quality. Determination of basicity. Part 1: Determination of general basicity and alkalinity towards phenolphthalein [in Polish].

19. PN-ISO 5813. 1983. Water quality. Determination of dissolved oxygen. Iodometric method [in Polish].

20. PN-ISO 7150-1.2002. Water quality. Determination of ammoniacal nitrogen. Part 1: Manual spectrometric method [in Polish].

21. Regulation of the Minister of the Environment dated 21 July 2016 on the classification of the surface water bodies and environmental quality standards for priority substances [OJ 2016, pos. 1187].

22. Schulz H.K., Śmietana P., Maiwald T., Oidtmann B., Schulz R. 2006. Case studies on the co-occurrence of Astacus astacus (L.) and Orconectes limosus (Raf.) - snapshots of a slow displacement. Freshwater Crayfish, 15, 212-219.

23. Water Framework Directive. Directive 2000/60/EC of the European Parliament and of the Council of 23 October 2000 establishing a framework for Community action in the field of water policy.

24. Whitton B.A., Ellwood N.T., Kawecka B. 2009. Biology of the freshwater diatom Didymosphenia: a review. Hydrobiol., 630, 1-37.

25. Zdoliński P. Górajek A., Lampart-Kałużniacka A. 2009. Applicability of biotic indices of macroinvertebrates to restoration assessment of the Pysznica river (the Parsęta basin, North Poland). Nauka Przyroda Technologie, 3(3), 109-116 [in Polish].

26. Zgrundo A., Peszek Ł., Pajączek A. 2018. A manual for monitoring and assessment of river surface water bodies based on phytobenthos. Gdańsk [in Polish].

27. http://www.katowice.pios.gov.pl (access: 30.06.2019)

28. http://mapy.geoportal.gov.pl (access: 03.06.2019)

29. http://www.gios.gov.pl (access 25.10.2018) 